\title{
THE DETERMINANTS OF CORPORATE SOCIAL RESPONSIBILITY DISCLOSURE: THE CASE OF MALAYSIAN GOVERNMENT-LINKED COMPANIES IN MALAYSIA
}

\author{
Assoc. Prof. Dr Hanim Norza Baba \\ Faculty of Accountancy, Universiti Teknologi MARA Melaka
}

\begin{abstract}
The implementation of Government-Linked Company (GLC) Transformation Program 2005/06 by government is one effort to promote Corporate Social Responsibility (CSR) disclosures among its government-linked companies (GLCs). CSR issues are being stressed in the Silver Book included in the GLC Transformation Manual under the GLC Transformation Program 2005/06. It is questionable as to whether the introduction of the Silver Book really reflects goods prospects for government-linked companies to disclose their CSR, and whether there are any other factors that will influence the GLCs in Malaysia to disclose their CSR. Thus, the objective of this study is to examine whether the introduction of the Silver Book affect the CSR disclosure among Malaysian GLCs as well as to examine the determinants of CSR disclosure, focusing on the profitability, board size and board independence. Multiple linear regression analysis is being used to examine the relationship between all the independent variables and dependent variable. Findings show that there is an increasing trend in CSR disclosure among Malaysian GLCs from year 2011 until 2015. Two variables i.e. board size and board independence has been found to have a significant positive relationship with the CSR disclosure. This study gives implications to various parties such as Malaysian Government, Bursa Malaysia, Security Commission and other relevant parties in to improve CSR awareness, practices, disclosures and quality in GLCs.
\end{abstract}

Keywords: GLC, CSR disclosure, board size, board independence

\section{INTRODUCTION}

Corporate social responsibility (CSR) disclosure is not new in Malaysia. The degree of awareness and engagement in CSR is not at an ignorance stage even though we are not a member of Organization for Economic Co-operation and Development (OECD) and only recognized as a developing country (Lo \& Yap, 2011). Research by Mohd Ghazali (2007) shows that there is an increase in CSR disclosures in Malaysian companies' annual reports as compared to the previous study done by Andrew, Gul, Guthrie, and Teoh (1989) and Baba \& Mohd Hanefah (2001). Change in public concern and awareness on environmental issues make companies in Malaysia provide environmental disclosures within the annual reports (Nik Ahmad, \& Sulaiman, 2004; Baba, 2004). According to Abd Rahman, Mohamed Zain and Yaakop Yahaya Al-Haj (2011), the traditional role of company's corporate reporting currently is being extended to social and environmental information, not only to financial

*Corresponding author's email: hanorza@melaka.uitm.edu.my 
information. Businesses' roles today also include an element of CSR and accountability and not only restricted to profit making purposes (Mohd Ghazali, 2007).

In Malaysia, Bursa Malaysia has made it mandatory for all listed companies to disclose CSR in their annual reports. Disclosing the social and environmental accounting practices would give better image and reputation to the companies as well as to increase the chances to secure contracts from the the government as it is seen as being socially responsible. CSR helps improve financial performance, enhance brand image and increase the ability to attract and retain the best workplace, contributing to the market value of the company ( $\mathrm{Said}, \mathrm{Hj}$ Zainuddin, \& Haron, 2009).

A number of CSR disclosure researches in Malaysia concerned with the determinants, level, theme and the form of disclosures (Baba \& Mohd Hanefah, 2001; Mohd Ghazali, 2007; Saleh, 2009; Abd Rahman et al., 2011; Lassaad \& Khamoussi, 2012); the current state, nature, quality and quantity of disclosures (Jaffar, Jamaludin, \& Che Abdul Raman, 2007; Ribeiro \& Aibar-Guzman 2010; Sibao \& Huaer, 2009; Lo \& Yap, 2011); to examine the determinants of CSR disclosures among public listed companies (PLCs) in Malaysia (Baba \& Mohd Hanefah, 2001; Said et al., 2009; Al Arussi, Selamat, \& Hanefah, 2009).

Issues concerning social and environmental matters have become more important in Malaysia nowadays. Companies should be aware of this responsibility and take action to ensure that they fulfill their obligations, role and status to the public (Baba, 2004). Companies will seek legitimacy if they are aware of the changes in public perception and awareness of the business to be socially responsible (Haider, 2010). In order to protect the companies selfinterest, the disclosures would show their positive contribution thereby improving the companies' image and reputation as well as legitimize their activities and managing the society.

The government also emphasizes that its controlled companies, GLCs, to be actively participate in the social and environmental responsibility, despite the growing pressures on the PLCs to be socially and environmentally responsible (Abd Rahman et al., 2011). The implementation of GLC Transformation Program 2005/06 by government is one effort to promote the CSR disclosures among GLCs. CSR issues are being stressed in the Silver Book, one of the initiatives included in the GLC Transformation Manual under the GLC Transformation Program 2005/06 (Esa \& Mohd Ghazali, 2012), and Khazanah Nasional Berhad, a key Government-Linked Investment Companies (GLIC), was tasked with the responsibility of monitoring Malaysian GLCs on the implementation of the CSR (Ching \& Wad, 2009). It is questionable, however, as to whether the introduction of the Silver Book really reflects goods prospects for GLCs to disclose their CSR, and whether there are any other factors that will influence the GLCs in Malaysia to disclose their CSR.

\section{LITERATURE REVIEW}

According to Siregar and Bachtiar (2010), board size has a positive and non-linear (quadratic and concave) relationship with CSR. This indicated larger board will be able to exercise better monitoring, but too large board will make the monitoring process ineffective. Firm size was found to have a positive effect on CSR, indicated that larger firms have more resources to devote to social activities and a larger asset base over which to spread the costs

[Type here] 
of social responsibility. In addition, larger firms also face more pressure to disclose their social activities for various groups in society.

A study by Mulyadi and Anwar (2012) that investigated the relationship between corporate governance and CSR disclosure of listed corporation in Indonesia Stock Exchange, focused on institutional ownership and independence of board toward the CSR disclosure. They developed CSR disclosure index based on Global Reporting Initiatives (GRI) indicators as a measurement of CSR disclosure. The study found that board independence and institutional ownership did not have influence to corporate CSR disclosure, while profitability was influential to corporate CSR disclosure at $1 \%$ significant.

A study by Esa and Mohd Ghazali (2012) in Malaysia investigated the change in the level of CSR disclosure among Malaysian GLCs for the years 2005 and 2011. The study also investigated whether corporate governance attributes influence CSR disclosure in corporate annual reports of Malaysian GLCs. Results from paired-sample t-tests showed that there was an increase in the extent of CSR disclosure at the 1 percent level, and multiple regression analysis revealed that board size was positively associated and statistically significant with the extent of CSR disclosure at the 1 percent level. The results implied that level of CSR disclosures increase after the introduction of the Silver Book in 2006, and GLCs with a larger board size disclosed significantly more CSR information than others in the sense that boards with more members with diverse experience and backgrounds exposed more healthier and livelier discussion on corporate social activities and hence improved investment in those activities.

\section{Profitability}

Profitability is the ability of company to earn profit or gain that would sustain the company's long-term and short-term growth (Lucyanda \& Siagian, 2012). One of the factors enabling management to disclose CSR activity in high level of flexibility is profitability (Mulyadi \& Anwar, 2012). According to Abd Rahman et al. (2011), high gap between the minimum and maximum values on profitability ratio indicating that certain companies are enjoying a good financial performance while some are not and their study found that profitability do not have any relationship with the level of CSR disclosure among Malaysian GLCs. Esa and Mohd Ghazali (2012) also found that there is no relationship between profitability and CSR disclosure. Pressure to disclose CSR is more influenced by "public" rather than "economic" pressure (Esa \& Mohd Ghazali, 2012). Said et al. (2009) on the other hand found that there is a significant positive relationship between profitability and the extent of CSR disclosure in Malaysian non-financial companies. This may due to the reason that profitable firms may have larger profit base to reach the costs of social responsibility and have more resources to allocate to social activities. More profitable firms would support more extensive social responsibility programs than less profitable firms because they have supplementary funds to do so (Luethge \& Han, 2012). Furthermore, management of profitable firms has more flexibility and there would be lack of restrictions to engage in and to disclose the social activities (Siregar \& Bachtiar, 2010).

\section{Board Size}

According to MCCG (revised 2011), every board should examine its size, with a view to determine the impact of the number upon its effectiveness and the board should include a

[Type here] 
balance of executive directors and non-executive directors (including independent nonexecutives) such that no individual or small group of individuals can dominate the board's decision making. As stated in the Green Book of the GLC Transformation Manual, board structure and board composition is the foundation of board effectiveness. To ensure that the board can effectively discharge its roles and responsibilities, there must be a sufficient number of directors held on the board. The size also should not become too large and unwieldy, which could then compromise board dynamics and the accountability of individual directors.

Vafeas (2000) proposes that a smaller board size can enhance the quality of financial reporting and, hence give better quality of information, while a larger board is expected to be less effective, as the monitoring responsibility will be dispersed among many directors. This may be because of the possibility that small board has better discussion of financial reporting numbers among their members as compared to a large board (Mohamad, Abdul Rashid, \& Shawtari, 2012). According to Siregar and Bachtiar (2010), larger board will be able to exercise better monitoring, but too large board will make the monitoring process ineffective. Esa and Mohd Ghazali (2012) found that board size positively associated and statistically significant with the extent of CSR disclosure among Malaysian GLCs. It shows that GLCs with a larger board size disclosed significantly more CSR information than others. They suggests that boards with more members have diverse experience and backgrounds so that they are more exposed to healthier and livelier discussion on corporate social activities and hence make more investment in those activities. On the contrary, Said et al. (2009) found that there is no relationship between board size and CSR disclosure.

\section{Board Independence}

MCCG (2012) strengthening the role of board by reinforcing the board independence. According to the MCCG (2012), the board should undertake an assessment of its independent directors annually and there must be majority of independence directors sit on the board. The Green Book in GLC Transformation Manual further provides that there should be no more than two Executive Directors and at least one-third of board is independence because a board with a balanced composition will ensure that no individual or small group of individuals will dominate decision-making.

Independent directors contribute to a good reporting system and when the investors observe that a firm has independent directors they believe that there is a monitoring function that is independent from the management to ensure such good reporting system (Siagian \& Tresnaningsih, 2011). Conversely, Esa and Mohd Ghazali (2012) argue that independent directors are a cost-efficient substitute for information disclosure. They found that larger proportion of independence directors disclose less CSR. Eng and Mak (2003) also found the same result where the higher the proportion of independence directors, the lower the information disclosed. Said et al. (2009) in their study does not found any relationship between board independence and the disclosure of CSR.

\section{Firm Size}

Firm size is considered as a control variable because it has been found to influence the CSR disclosures. According to Aldama, Amar and Trostianki (2009), size of the company is strongly associated with the CSR structuring and CSR strategies in terms of its employees

[Type here] 
and revenues. Larger company has bigger chance to find a structured area and tend to declare more sustainable development-related policies. Since large companies have the more resources to collect, analyze and report data, they tend to disclose more information than small size companies (Al-Shubiri et al., 2012). Larger companies are supposed to disclose more CSR information in order to expose or portray their corporate citizenship, in so doing legitimizing their existence (Mohd Ghazali, 2011). The firm size for Malaysian GLCs is a significant item to measure the disclosure of CSR information (Abd Rahman et al., 2011). Nevertheless, study by Bayoud, Kavanagh, \& Slaughter (2012) found that levels of CSR disclosure do not seem to be affected by company size in Libyan companies.

\section{Legitimacy Theory}

Legitimacy is a generalized perception or assumption that the actions of an entity are desirable, proper, or appropriate within some socially constructed system of norms, values, beliefs, and definitions (Suchman, 1995, p. 574). Legitimacy theory is used as a communication mechanism to inform or manipulate the perceptions of the firm's actions. Islam and Deegan (2008) state that legitimacy theory asserts that organisations attempt to ensure that their activities are perceived by outside parties as being legitimate in order to ensure that they are perceived as operating within the bounds and norms of their respective societies. Besides that, legitimacy theory posits that businesses are bound by the social contract in which the firms agree to perform various socially desired actions in return for approval of its objectives and other rewards, and this ultimately guarantees its continued existence. Thus, firms use communication or accounting to defend or maintain their legitimacy in the eyes of the society.

According to Islam and Deegan (2010), there is a 'social contract' between an organization and the society (societies) in which it operates, and there will be some negative implications for the ongoing survival of the organization if there is any breach of the social contract. In a sense management seeks congruence between the outside perceptions of its own organization's social values and what is deemed by society to be appropriate social conduct, management seeks to maintain or establish its legitimacy (Deegan \& Gordon, 1996). Observer groups such as audiences or relevant publics evaluate the organization based on their perceptions and assumptions regarding congruence between their values and organizational values and if the relevant audiences are not aware of the divergence, that organization may materially diverge from expectations and still maintain its legitimacy (Mobus, 2005). In addition, O'Sullivan and O'Dwyer (2009) emphasize that accountability and moral legitimacy pay attention to the societal values and expectations from an organizational perspective. In a nutshell, company should provide CSR information by reporting the CSR activities to the society and behave according to the legitimacy theory in order to remain competitive and survive in the market, as well as to make itself accountable to the public and society.

\section{HYPOTHESES DEVELOPMENT}

Singhvi and Desai (1971) argue that when the company achieves a high margin of profit and there is a high rate of return, the managerial groups are motivated to disclose more information in order to show off good reputation to the consumers, shareholders, investors and other stakeholders. Contrary, if the company suffers losses or there is a low rate of

[Type here] 
return, the managerial groups may disclose less information in order to cover the reasons for such losses or declining profits (Al Arussi et al., 2009). One of the factors enabling management to disclose CSR activity in high level of flexibility is profitability (Mulyadi \& Anwar, 2012).

However, literature shows that the results on the association between profitability and CSR disclosure were mixed. Mohamed Zain and Janggu (2006), Jaffar et al. (2007) and Said et al. (2009) found that there is a positive association between profitability and CSR disclosure, while Abdul Rahman et al. (2015) and Esa and Mohd Ghazali (2012) found that there is a no association or relationship between profitability and CSR disclosure. They found that profitability does not influence CSR disclosure made by companies. Due to the mixed findings, the first hypothesis will be as follows:

\section{H1: $\quad$ There is a significant relationship between profitability and CSR disclosure among GLCs in Malaysia.}

One of the most important elements of corporate governance mechanism is a board of directors who has the role to oversee and ensure that agents have properly managed the business (Said et al., 2009). MCCG (revised 2011) does not state the exact number on how many directors should be on the board to ensure the effectiveness but it suggests that there should be a balance between executive and non-executive directors on the board. The Green Book in the GLC Transformation Manual also does not state on the appropriate number, however, in order to ensure board can effectively discharge its roles and responsibilities, there must be a sufficient number of directors held on the board, where it should not become too large and unwieldy, which could then compromise board dynamics and the accountability of individual directors. Research regarding the investigation of the relationship between board size and CSR disclosure is rarely conducted (Esa \& Mohd Ghazali, 2012). Only few researches have focus on this factor (board size). Siregar and Bachtiar (2010) and Esa and Mohd Ghazali (2012) in their study found that there is a positive relationship between board size and CSR disclosure. Their findings show that larger board size has higher influence on CSR disclosure, as larger board size exercises better monitoring and controlling function. Said et al. (2009) on contrary do not found any relationship between board size and CSR. The next hypothesis developed is:

H2: $\quad$ There is a significant relationship between board size and CSR disclosure among GLCs in Malaysia.

In corporate governance context, when arriving at board decisions, independent directors are supposed to perform a monitoring role ensuring that shareholders' interests are taken into consideration (Esa \& Mohd Ghazali, 2012). The Green Book in GLC Transformation Manual as well as MCCG 2012 encourages companies in Malaysia to have strong independence on board. There should be at least one-third independent directors sit on the board to monitor and provide independent view and judgment. Literature regarding the relationship between board independence and CSR disclosure are found to have a mixed result. Eng and Mak (2003) and Esa and Mohd Ghazali (2012) found a negative relationship between board independence and CSR disclosure whereas Donnelly and Mulcany (2008) found a negative relationship. Said et al. (2009) found no relationship between board independence and CSR disclosure. The mixed findings lead to the following hypothesis: 
H3: $\quad$ There is a significant relationship between board independence and CSR disclosure among GLCs in Malaysia.

Table A: The operationalization of variables

\begin{tabular}{|c|c|c|c|}
\hline Variables & Abbreviation & Operationalization & Reference \\
\hline Dependent Variable & & & \\
\hline $\begin{array}{l}\text { Corporate Social } \\
\text { Responsibility Disclosures }\end{array}$ & CSRD & $\begin{array}{l}\text { Number of words from } \\
\text { all four themes i.e. } \\
\text { human resources, } \\
\text { community, marketplace } \\
\text { and environment stated } \\
\text { in annual reports }\end{array}$ & $\mathrm{Ng}(1985)$ \\
\hline
\end{tabular}

Independent Variables

Profitability

PROFIT Profit before tax over Esa and Mohd Ghazali

total assets

(2012)

Board Size

BSIZE

Total number of

Said et al. (2009)

directors sit on the board

Board Independence

Control Variable

Firm Size
IND

FSIZE
Percentage of independent directors to total number of directors sit on the board

$\log 10$ of total assets
Esa and Mohd Ghazali

(2012)

Abd Raman et al. (2015)

\section{RESEARCH METHODOLOGY}

Research design for this study is based on quantitative approach and longitudinal study of which investigate the relationship between CSR disclosures with corporate governance characteristics and firm characteristics. Annual reports for five years starting from year 2011 until 2015 of 16 GLC listed on Bursa Malaysia are taken from the Bursa Malaysia website (www.bursamalaysia.com). This study does not rely on the list of GLCs published on The Putrajaya Committee on GLC High Performance (PCG) website as it is outdated at the time of this writing. The author identify GLCs as Malaysian listed companies with $20 \%$ equity shares held by GLICs (Zin \& Sulaiman, 2011). The findings of this study was analyzed using Statistical Package for Social Science (SPSS) version 22.0. Descriptive statistics will be used to identify the frequency distribution, central tendency (mean, median and mode) and dispersion (maximum, minimum and standard deviation) of all variables. Multiple regression analysis will be used to examine the relationship between the dependent variable i.e. CSR disclosures and the independent variables i.e. firm characteristics and corporate governance characteristics. Multiple regression analysis is used to find the result of all hypotheses developed in this study. The regression model of this study is as follows:

$\mathrm{CSRD}=\beta_{0}+\beta_{1}$ PROFIT $+\beta_{2} \mathrm{BSIZE}+\beta_{3} \mathrm{IND}+\beta_{4} \mathrm{FSIZE}+\varepsilon$

[Type here] 
Where:

CSRD

$=$ total CSR disclosures

$\beta_{0}$

$=$ intercept coefficient, when all other independent variables are zero

PROFIT = profit before tax over total assets

BSIZE $=$ total number of directors sit on the board

IND = percentage of independent directors to total number of directors sit on the board

FSIZE $\quad=\log 10$ of total assets

$\varepsilon=$ standard normal, randomly distributed error term

\section{FINDINGS AND DISCUSSION}

Descriptive statistics is executed to describe and summarize the characteristics of the sample. Tables presented below show the descriptive results for all variables utilized in this study based on the corporate annual report from year 2015 until 2015. Tables below report the minimum, maximum, mean and standard deviation.

Table B: Descriptive Statistics of firm's characteristics, corporate governance characteristics and control variable

\begin{tabular}{|c|c|c|c|c|c|}
\hline Variables & $N$ & Minimum & Maximum & Mean & Std. Deviation \\
\hline \multicolumn{6}{|l|}{2015} \\
\hline PROFIT & 16 & 0.006 & 17.115 & 1.18419 & 4.250660 \\
\hline BSIZE & 16 & 6 & 12 & 9.19 & 1.515 \\
\hline IND & 16 & 0.300 & 0.625 & 0.47638 & 0.097712 \\
\hline FSIZE & 16 & 8.36 & 10.94 & 9.5412 & 0.73186 \\
\hline \multicolumn{6}{|l|}{2012} \\
\hline PROFIT & 16 & 0.004 & 14.229 & 0.93869 & 3.544552 \\
\hline BSIZE & 16 & 6 & 12 & 9.19 & 1.601 \\
\hline IND & 16 & 0.286 & 0.778 & 0.46588 & 0.124154 \\
\hline FSIZE & 16 & 8.34 & 10.80 & 9.6152 & 0.65384 \\
\hline \multicolumn{6}{|l|}{2013} \\
\hline PROFIT & 16 & 0.004 & 1.608 & 0.14481 & 0.393101 \\
\hline BSIZE & 16 & 6 & 13 & 9.38 & 1.857 \\
\hline IND & 16 & 0.300 & 0.778 & 0.49500 & 0.115590 \\
\hline FSIZE & 16 & 8.38 & 11.11 & 9.7018 & 0.72616 \\
\hline \multicolumn{6}{|l|}{2014} \\
\hline PROFIT & 16 & 0.009 & 19.270 & 1.26763 & 4.800925 \\
\hline BSIZE & 16 & 6 & 15 & 9.69 & 2.301 \\
\hline
\end{tabular}

[Type here] 


$\begin{array}{lrrrrr}\text { IND } & 16 & 0.273 & 0.778 & 0.51038 & 0.124858 \\ \text { FSIZE } & 16 & 8.40 & 10.84 & 9.6857 & 0.62399 \\ 2015 & & & & & \\ \text { PROFIT } & 16 & 0.004 & 15.533 & 1.11094 & 3.856695 \\ \text { BSIZE } & 16 & 6 & 12 & 9.25 & 1.880 \\ \text { IND } & 16 & 0.333 & 0.778 & 0.50306 & 0.134819 \\ \text { FSIZE } & 16 & 8.47 & 10.82 & 9.7273 & 0.61960\end{array}$

Note: PROFIT $=$ profitability measured by profit before tax over total assets; BSIZE $=$ board size measured by total number of directors sit on the board; IND = board independence measured by percentage of independent directors to total directors sit on the board; FSIZE $=$ firm size measured by $\log 10$ of total assets.

Table B presents the descriptive statistics for all independence variables i.e. firm characteristics and corporate governance characteristics as well as the control variable used in this study. The results show that the worst profitability that Malaysian GLCs obtain is in year 2013 because the minimum profitability is $0.004 \%$ and the maximum profitability is only $1.608 \%$, while the optimum profitability that Malaysian GLCs obtain is in year 2014 where the minimum profitability is $0.009 \%$ and the maximum profitability is $19.270 \%$. The results also show that mean or average profitability for Malaysian GLCs reduce from year 2011 to year 2012 and 2013, but increase back in year 2014. In year 2015, the average profitability decrease by $0.157 \%$ from the previous year.

The table also explains descriptive statistics including the minimum, maximum, mean and standard deviation for corporate governance characteristics in Malaysian GLCs. In term of board size, the results show that over the five years period studied, the minimum number of directors sit on Malaysian GLCs board is 6 while the maximum number of directors sit on Malaysian GLCs board is 15 . In average, there are 9 directors sit on the board of Malaysian GLCs.

In term of board independence, the results indicate that not all Malaysian GLCs follow the guideline in the Green Book where there should be one-third of independent directors sit on the board to ensure the independence on the board. In average, the results show that there is no slight different in the percentage of independent directors sit on the board for the five consecutive years.

Finally, firm size as a control variable, the results show that there is slightly similar in term of size of the GLCs in Malaysia for the five consecutive years, in which the biggest size is 11.11 comes from year 2013. In average, these indicate that Malaysian GLCs are almost similar in size when they are measured in term of total assets held by the companies. 
Table C: Descriptive Statistics of corporate social responsibility disclosures by general themes

\begin{tabular}{|c|c|c|c|c|c|c|}
\hline & $N$ & Sum & Minimum & Maximum & Mean & $\begin{array}{c}\text { Std. } \\
\text { Deviation }\end{array}$ \\
\hline \multicolumn{7}{|l|}{2011} \\
\hline Human Resource & 16 & 4062 & 0 & 873 & 253.88 & 283.257 \\
\hline Community & 16 & 4789 & 117 & 2970 & 1093.13 & 907.319 \\
\hline Marketplace & 16 & 2024 & 0 & 780 & 126.50 & 231.454 \\
\hline Environment & 16 & 3608 & 0 & 879 & 225.50 & 248.012 \\
\hline CSRD & 16 & 14483 & 245 & 4178 & 1699.00 & 1298.358 \\
\hline \multicolumn{7}{|l|}{2012} \\
\hline Human Resource & 16 & 3986 & 0 & 1703 & 535.88 & 578.776 \\
\hline Community & 16 & 6476 & 180 & 3145 & 880.75 & 758.435 \\
\hline Marketplace & 16 & 2351 & 0 & 1265 & 226.00 & 411.919 \\
\hline Environment & 16 & 5340 & 0 & 975 & 333.75 & 298.599 \\
\hline CSRD & 16 & 18153 & 180 & 5823 & 1976.38 & 1634.691 \\
\hline \multicolumn{7}{|l|}{2013} \\
\hline Human Resource & 16 & 5958 & 0 & 1386 & 459.00 & 392.190 \\
\hline Community & 16 & 6951 & 172 & 2020 & 805.38 & 612.862 \\
\hline Marketplace & 16 & 2604 & 0 & 754 & 162.75 & 193.735 \\
\hline Environment & 16 & 3808 & 0 & 1934 & 471.06 & 575.318 \\
\hline CSRD & 16 & 19321 & 172 & 5201 & 1898.19 & 1305.388 \\
\hline \multicolumn{7}{|l|}{2014} \\
\hline Human Resource & 16 & 4881 & 0 & 5108 & 910.19 & 1231.643 \\
\hline Community & 16 & 3087 & 279 & 9919 & 1859.56 & 2347.310 \\
\hline Marketplace & 16 & 3556 & 0 & 2741 & 393.56 & 670.988 \\
\hline Environment & 16 & 5414 & 0 & 2278 & 689.00 & 659.766 \\
\hline CSRD & 16 & 16938 & 352 & 20046 & 3852.31 & 4629.711 \\
\hline \multicolumn{7}{|l|}{2015} \\
\hline Human Resource & 16 & 5636 & 0 & 3622 & 785.44 & 839.297 \\
\hline Community & 16 & 4564 & 248 & 6052 & 1737.31 & 1921.979 \\
\hline Marketplace & 16 & 3364 & 0 & 2212 & 348.50 & 557.659 \\
\hline Environment & 16 & 4614 & 0 & 1805 & 653.06 & 548.301 \\
\hline CSRD & 16 & 18178 & 344 & 13129 & 3524.31 & 3164.919 \\
\hline
\end{tabular}

Table C presents the frequency analysis for CSR disclosures by four general themes i.e. human resources, community, marketplace and environment as well as the total CSR disclosures from year 2011 until year 2015. It shows that the highest CSR disclosure in year 2011 is under community theme, while the lowest disclosure is under marketplace theme. The highest CSR disclosure in year 2012 is under community theme, while the lowest [Type here] 
disclosure is under marketplace theme, same with the previous year. In year 2013, the highest CSR disclosure is under community theme, while the lowest disclosure is under marketplace theme, same also with the previous years. In year 2014, the highest CSR disclosure is under environment theme, but in average is under community theme. The lowest disclosure is again found to be under marketplace theme, same with the previous years. Lastly, in year 2015, the highest CSR disclosure is under human resources theme, but in average is under community theme. The lowest disclosure is still under marketplace theme, same with the previous years. Overall, the result indicates that the introduction of the Silver Book really reflect a CSR disclosure among Malaysian GLCs.

\section{Correlation}

Correlation measures the strength, direction and significant relationship between independent and dependent variables. According to Pallant (2011), multicollinearity may be a problem when the correlation exceeded 0.7 . Hence, to verify for multicollinearity problem, Table D below shows the result of the correlation matrix.

Table D: Spearman's Correlations Coefficient Matrix

\begin{tabular}{|c|c|c|c|c|c|}
\hline & CSRD & PROFIT & BSIZE & IND & FSIZE \\
\hline CSRD & 1.000 & .187 & $.440^{* *}$ & .196 & $.372^{* *}$ \\
\hline PROFIT & & 1.000 & .217 & .157 & -.194 \\
\hline BSIZE & & & 1.000 & .197 & $.255^{*}$ \\
\hline IND & & & & 1.000 & .093 \\
\hline FSIZE & & & & & 1.000 \\
\hline
\end{tabular}

Note: PROFIT $=$ profitability measured by profit before tax over total assets; BSIZE $=$ board size measured by total number of directors sit on the board; IND = board independence measured by percentage of independent directors to total directors sit on the board; FSIZE = firm size measured by $\log 10$ of total assets.

As shown in Table D, CSRD is significantly positive correlated with BSIZE at 0.440 and FSIZE at 0.372. Therefore, it can be concluded that multicollinearity is not a serious problem, and the use of parametric statistical analysis such as regression analysis for all variables is considered appropriate for this study.

\section{Regression Analysis}

Table E below summarizes the regression analysis results for the data of the relationship between the dependent variable i.e. corporate social responsibility disclosure (CSRD) and the independent variables i.e. profitability (PROFIT), board size (BSIZE), and board independence (IND). 
Table E: Multiple Linear Regression Analysis

\begin{tabular}{|c|c|c|c|c|}
\hline & Variables & Coefficients & $\begin{array}{c}\text { Significant } \\
\text { (T-Stat) }\end{array}$ & P-value \\
\hline Dependent & CSRD & & & \\
\hline \multicolumn{5}{|l|}{ Variable } \\
\hline \multirow{2}{*}{ Independent } & (Constant) & 1.709 & 0.66 & 0.511 \\
\hline & PROFITABILITY & 3.250 & 1.992 & 0.055 \\
\hline \multirow{2}{*}{ Variables } & BSIZE & 0.097 & 1.604 & $0.043^{*}$ \\
\hline & IND & 1.326 & 1.466 & $0.037 *$ \\
\hline Control & FSIZE & 0.108 & 0.503 & 0.116 \\
\hline \multicolumn{5}{|l|}{ Variable } \\
\hline & $\mathrm{N}$ & 80 & & \\
\hline & $\mathrm{R}^{2}$ & 0.179 & & \\
\hline & Adjusted $\mathrm{R}^{2}$ & 0.169 & & \\
\hline & F-value & 17.06 & & \\
\hline & P-value & 0 & & \\
\hline
\end{tabular}

*significant at 0.05

Note: PROFIT $=$ profitability measured by profit before tax over total assets; BSIZE $=$ board size measured by total number of directors sit on the board; IND = board independence measured by percentage of independent directors to total directors sit on the board; FSIZE = firm size measured by $\log 10$ of total assets.

Table E shows that F-value for the data is statistically not significant at the 1 percent level where the p-value is 17.060 (more than 0.05). It indicates that the independent variables in this study are not significant to measure the dependent variable. The $\mathrm{R}^{2}$ is 0.179 and the adjusted $\mathrm{R}^{2}$ is 0.169 . It can be concluded that $17.9 \%$ variance in corporate social responsibility disclosure (CSRD) is explained by all the independent variables i.e. PROFIT, BSIZE, IND and another $82.1 \%$ variance in CSRD might be explained by the other factors or variables that have not been used in this study. Referring to the P-value, there are only two variables that make a statistically significant contribution (less than 0.05) toward CSRD which are BSIZE and IND, where the highest coefficient value is IND $(p=0.037)$. Both BSIZE $($ Beta $=0.097)$ and IND (Beta $=1.326)$ were found significantly positive correlated with the corporate social responsibility disclosure. This suggests that bigger board size has various background, skill and experience to promote CSR, thus lead to higher level of CSR disclosure, and higher proportion of independent directors sit on the board will have stronger monitoring control, thus lead to higher level of CSR disclosure among Malaysian GLCs.

Based on the results tabulated in Table E above, the regression model for corporate social responsibility disclosure in relation to firm' characteristics and corporate governance characteristics can be expressed as follows:

$\mathrm{CSRD}=1.709-3.250($ PROFIT $)+0.097(\mathrm{BSIZE})+1.326(\mathrm{IND})+0.108(\mathrm{FSIZE})+\varepsilon$

[Type here] 
This model suggests that CSR disclosure among GLCs in Malaysia could be significantly enhanced by increasing the number of directors sit on the board as well as increasing the involvement of independent directors sit on the board.

\section{Relationship between profitability and CSR disclosure}

The above result shows that there is no significant relationship between profitability and CSR disclosure. Therefore, hypothesis $\mathrm{H}_{1}$ is rejected. This result is consistent with Abdul Rahman et al. (2015) and Said et al. (2009). It indicates that profitability does not influence the CSR disclosure made by Malaysian GLCs.

\section{Relationship between board size and CSR disclosure}

The regression result shows that board size has significant positive relationship with the CSR disclosure. It indicates that large number of directors sit on the board provide better disclosure of CSR. Whereas, small number of directors sit on the board lead to weaker disclosure of CSR in Malaysian GLCs annual reports. Hence, hypothesis $\mathrm{H}_{4}$ is supported. This result is parallel with the results of previous studies conducted by the other researchers (Siregar \& Bachtiar, 2010; Esa \& Mohd Ghazali, 2012). This result indicates that larger board size is more effective and having various background, skills and knowledge enhance the disclosure of CSR activities in the company's annual reports.

\section{Relationship between board independence and CSR disclosure}

Based on the table above, there is a significant positive relationship between board independence and CSR disclosure. It shows that higher proportion of independence directors over total number of directors sit on the board provide greater CSR disclosure. On contrary, lower proportion of independence directors over total number of directors sit on the board lead to the smaller amount of CSR disclosed by Malaysian GLCs in their annual reports. Therefore, hypothesis H5 is supported. This result is consistent with Eng and Mak (2003) and Esa and Mohd Ghazali (2012). It indicates that higher percentage of independent directors sit on the board would enhance the monitoring and controlling function so that companies would provide sufficient disclosure on the CSR information to public and all stakeholders.

\section{CONCLUSION}

Malaysian government has made it mandatory for all public listed companies (PLCs) in Malaysia to report and disclose their CSR. In order to protect interest of all stakeholders, there is a need for a company to report their social responsibility. Reporting CSR will enhance public confidence and give better image and reputation for the companies. Malaysian GLCs, whose majority shares are owned by government also, need to report and disclose their CSR to obtain such benefits. As what has been presented in the descriptive analysis, the trend of CSR disclosure in Malaysian GLCs is increasing over the years, indicating that Malaysian GLCs are become more and more concern about their social responsibility in term of human resources, community, marketplace and environmental matters, which the most focus is on the community matters such as education, disaster relief, charity, sports and cultures. The increasing trend of disclosure also proves that the

[Type here] 
introduction of the Silver Book really reflect a better CSR disclosure among Malaysian GLCs. Also, CSR disclosure made by Malaysian GLCs is influenced by certain corporate governance characteristics i.e. board size and board independence. Firm characteristics on the other hand do not influence the CSR disclosure made by Malaysian GLCs.

Accordingly, higher number of directors sits on the board increase the level of CSR disclosure due to the excessively skills and experience to improve CSR awareness in the companies. Higher percentages of independence directors sit on the board also increase the level of CSR disclosure because monitoring and controlling function are enhanced through the higher level of independence. In addition, although different firm or company has different characteristics, there is nothing to do with the level of CSR disclosure.

\section{REFERENCES:}

Abd Rahman, N.H., Mohamed Zain, M., \& Yaakop Yahaya Al-Haj, N.H. (2011). CSR disclosures and its determinants: evidence from Malaysian government link companies. Social Responsibility Journal, 2(2), 181-201.

Al Arussi, A.S., Selamat, M.H., \& Hanefah, M.M. (2009). Determinants of financial and environmental disclosures through the internet by Malaysian companies. Asian Review of Accounting , 17(1), 59-76.

Aldama, L.R., Amar, P.A., \& Trostianki, D.W. (2009). Embedding corporate responsibility through effective organizational structures. Corporate Governance, 9(4), 506-516.

Al-Shubiri, F.N., Al-abedallat, A.Z., \& Orabi, M.M. (2012). Financial and non financial determinants of corporate social responsibility. Asian Ecomonic and Financial Review, 2(8), 1001-1012.

Andrew, B.H., Gul, F.A., Guthrie, J.E., \& Teoh, H.Y. (1989). A note on corporate social disclosure practices in developing countries: the case of Malaysia and Singapore. British Accounting Review, 21, 371-376.

Baba, H.N. \& Mohd Hanefah, H.M. (2001). Corporate social disclosure practices in Malaysia. Presented at the $2^{\text {nd }}$ Asean Academic Accounting Association Conference, Shangrila Hotel, Penang.

Baba, H.N. (2004). Corporate social responsiveness and environmental performance of smallmedium enterprises: An Empirical Study. Unpublished PhD thesis.

Bayoud, N.S., Kavanagh, M., \& Slaughter, G. (2012). Factors influencing levels of corporate social responsibility disclosure by Libyan firms: a mixed study . International Journal of Economic and Finance, 4(4), 13-29.

Bursa Malaysia (2006), CSR Framework for Malaysian PLCs, retrieved 3 April 2012, from http://ablemen.com/sustainability/lock/frameworks introduction.php?page=frameworks $\underline{\text { \&index }}=1$

Ching, S.C. \& Wad, P. (2009). Corporate social responsibility and offshore outsourcing: electrical and electronics firms in malaysia. International Journal of Institutions and Economies, 1, 253-282.

Corporate Governance Blueprint (2011), retrieved 3 April 2013 from http://www.sc.com.my/main.asp?pageid=1087\&menuid=\&newsid=\&linkid=\&type=

Deegan, C. \& Gordon, B. (1996). A Study on the Environmental Disclosure Practices of Australian Corporations. Accounting and Business Research, 26(3), 187-199.

Donnelly, R. \& Mulcany, M. (2008). Board structure, ownership and voluntary disclosure in Ireland. Corporate Governance: An International Review , 16(5), 416-429.

[Type here] 
Eng, L.L., \& Mak, Y.T. (2003). Corporate governance and voluntary disclosure. Journal of Accounting and Public Policy, 22, 325-345.

Esa, E. \& Mohd Ghazali, N.A. (2012). Corporate social responsibility and corporate governance in Malaysian government-linked companies. Corporate Governance, 12(3), 292-305.

Islam, M.A., \& Deegan, C. (2008). Motivations for an organisation within a developing countryto report social responsibility information; Evidence from Bangladesh. Accounting, Auditing \& Accountability Journal, 21(6), 850-874.

Islam, M.A., \& Deegan, C. (2010). Media pressures and corporate disclosure of social responsibility performance information: a study of two global clothing and sports retail companies. Accounting and Business Research, 40(2), 131-148.

Jaffar, R., Jamaludin, S., \& Che Abdul Rahman, M.R. (2007). Determinant factors affecting quality of reporting in annual reports of Malaysian companies. Malaysian Accounting Review , 6(2), 19-39.

Lassaad, B.M., \& Khamoussi, H. (2012). Determinanst of Communication about Corporate Social Responsibility: Case of French Companies. International Journal of Contemporary Business Studies, 3(5), 49-60.

Lo, B.C.W. \& Yap, K.L. (2011). Are Malaysian Companies Ready For Corporate Social Responsibility? Labuan e-Journal of Muamalat and Society, 5, 11-15.

Lucyanda, J. \& Siagian, L.G. (2012). The influence of Company Characteristics Toward Corporate Social Responsibility Disclosure. The 2012 International Conference on Business and Management, 601-619.

Luethge, D. \& Han, H.G. (2012). Assessing corporate social and financial performance in China. Social Responsibility Journal, 8(3), 389-403.

MCCG (2012). Malaysian Code on Corporate Governance, retrieved 20 April 2013 from http://www.sc.com.my/eng/html/cg/cg2012.pdf

MCCG (revised 2007). Malaysian Code on Corporate Governance, retrieved 20 April 2013 from http://www.sc.com.my/eng/html/cg/cg2007.pdf

Mobus, J.L. (2005). Mandatory environmental disclosures in a legitimacy theory context. Accounting, Auditing \& Accountability Journal, 18(4), $492-517$.

Mohamad, M.H., Abdul Rashid, H.M., \& Shawtari, F.A. (2012). Corporate governance and earnings management in Malaysian government linked companies; The impact of GLCs' transformation policy. Asian Review of Accounting, 20(3), 241-258.

Mohamed Zain, M. \& Janggu, T. (2006). Corporate social disclosure (CSD) of construction companies in Malaysia. Malaysian Accounting Review, 5(1), 85-144.

Mohd Ghazali, N.A. (2007). Ownership structure and corporate social responsibility disclosure: some Malaysian evidence. Corporate Governance, 7(3), 251-266.

Mulyadi, M.S. \& Anwar, Y. (2012). Influence of corporate governance and profitability to corporate CSR disclosure. International Journal of Arts and Commerce, 1(7), 29-35.

Nik Ahmad, N.N. \& Sulaiman, M. (2004). Environmental disclosures in Malaysian annual reports: A legitimacy theory perspectives. International Journal of Cost Management, 14(1), 44-58.

O'Sullivan, N. \& O'Dwyer, B. (2009). Stakeholder perspectives on a financial sector legitimation process: The case of NGOs and the Equator Principles. Accounting, Auditing \& Accountability Journal, 22(4), 553-587.

Pallant, J. (2011). SPSS Survival Manual (4th edition): A step by step guide to data analysis using SPSS for Windows. Open University Press. 
Putrajaya Committee (2006). GLC Transformation Manual, retrieved 3 April 2013 from http://www.pcg.gov.my/trans_manual.asp

Ribeiro, V.P. \& Aibar-Guzman, C. (2010). Determinants of environmental accounting practices in local entities: evidence from Portugal. Social Responsibility Journal, 6(3), 404-419.

Said, R., Hj Zainuddin, Y., \& Haron, H. (2009). The relationship between corporate social responsibility disclosure and corporate governance characteristics in Malaysian public listed companies. Social Responsibility Journal, 5(2), 212-226.

Saleh, M. (2009). Corporate Social Responsibility Disclosure in an Emerging Market: A Longitudinal Analysis Approach. International Business Research, 2(1), 131-141.

Siagian, F.T., \& Tresnaningsih, E. (2011). The impact of independence directors and independence audit committees on earnings quality reported by Indonesian firms. Asian Review of Accounting, 19(3), 192-207.

Sibao, S. \& Huaer, C. (2009). Economic globalization and the construction of China's corporate social responsibility. International Journal of Law and Management, 51(3), 134-138.

Singhvi, S.S. \& Desai, H.B. (1971). An empirical analysis of the quality of corporate financial disclosure. The Accounting Review, 46(1), 129-138.

Siregar, S.V. \& Bachtiar, Y. (2010). Corporate social reporting: empirical evidence from Indonesia Stock Exchange. International Journal of Islamic and Middle Eastern Finance and Management, 3(3), 241-252.

Suchman, M.C. (1995). Managing Legitimacy: Strategic and Institutional Approaches. Academy of Management Review, 20(3), 571-610.

Vafeas, N. (2000). Board structure and the informativeness of earnings. Journal of Accounting and Public Policy, 19(2), 136-160. 